\title{
Transgressive Segregation and Interrelationship Analysis in Soybean
}

\author{
B. A. Tagad*, V. S. Girase, Rohini Y. Patil and V. V. Bhavsar \\ Department of Botany, College of Agriculture, (M S), Dhule, India \\ *Corresponding author
}

\begin{abstract}
A B S T R A C T
Soybean is economically the most important bean in the world, providing vegetable protein for millions of the people and ingredients for hundreds of chemical products. The aim of this study was to identify the superior transgressive segregants and estimate the correlation coefficient between seed yield, and yield components. Six generations of a crosses were evaluated at Botany Section Farm, College of Agriculture, Dhule (Maharashtra) during Kharif, 2019. The field experiment was arranged in a randomized block design (RBD) with non-replicated fashion. In general, the highest proportion of transgressive segregants were recorded for plant height (28) followed by grain yield per plant (26), number of pods per plant (15), number of seeds per pod (10),100-grain weight (10) and number of primary branches(3). The most promising transgressive segregants observed in F2 generation were Plant No.379 of this cross. Phenotypic correlation of grain yield per plant with nine other characters studied in $\mathrm{F}_{2}$ generation of this cross indicated, significant and positive correlations with three other characters viz; number of primary branches per plant, number of pods per plant, number of seeds per pod. These characters also showed significant and positive correlation among themselves uniformly. From the above observations the improvement in grain yield of soybean appears to be possible by selection through aforesaid characters.
\end{abstract}

\section{Introduction}

Soybean, (glycine max), also called soja bean or soya bean, annual legume of the pea family (fabaceae) and its edible seed. The soybean is economically the most important bean in the world, providing vegetable protein for millions of the people and ingredients for hundreds of chemical products. Like other legumes the plant adds nitrogen to the soil by means of nitrogen-fixing bacteria and historically has been an important soil enriching crop, though this practice is not common in most industrial agriculture systems.

The soybean is one of the richest and cheapest sources of protein and is a staple in the diets of people and animals in numerous parts of the world. The seed contains 17 percent oil and 63 percent meal, 50 percent of which is protein. Because soybeans contain no starch, they are good source of protein for diabetics. In East Asia the bean is extensively consumed in the forms of soy milk, a whitish liquid suspension, and tofu a curd somewhat 
resembling cottage cheese. Soybean are also sprouted for use as a salad ingredient or as a vegetable and may be eaten roasted as a snack food. Yong soybeans, known as edamame, are commonly steamed or boiled and eaten directly from the pod. The area under soybean crop during 2020-21 in Maharashtra is 39.29 lakh hectare and production 45.13 lakh tone with productivity $1148 \mathrm{~kg} / \mathrm{ha}$.

\section{Materials and Methods}

The field experiment was conducted at Botany Section Farm, College of Agriculture, Dhule (India), The single direct cross was effected by using two diverce parents viz; KDS-726, NRC-102,during kharif-2018 and $F_{1}$ 's grown to obtain $F_{2}$ seeds during Summer2019. The experimental material were evaluated in randomized block design with non-replicated fashion. Recommended doses of fertilizers and cultural practices were adopted. Two rows for parents and twenty five rows for $F_{2}$ generation of $4 \mathrm{~m}$ length and $45 \mathrm{~cm}$ apart accommodating 1000 plants at $10 \mathrm{~cm}$ distance between plants. At random 600 plant from $\mathrm{F}_{2}$ generation and 10 plants from parent plot were tagged for recording observations on ten characters. viz., days to $50 \%$ flowering, days to maturity, plant height, number of primary branches per plant, no of pods per plant, no of seeds per pod, 100 grain weight, oil content (\%), protein content (\%) and grain yield per plant. For understanding the association among the yield and yield contributing character, correlation coefficients were worked out by using the data of $600 \mathrm{~F}_{2}$ plants of a cross, as per the procedure of Dewey and Lu (1959). Statistical analysis was carried out as per the procedure given by Panse and Sukhatme (1995). Transgressive segregants were estimated by calculating threshold value by following formula.

1. Correlation coefficient $(\mathrm{rPxy})=\underline{\mathrm{Cov}}$ xy $\sqrt{ }$ Vx.Vy Where,
Cov.xy $=$ Covariance between the characters $\mathrm{x}$ and $\mathrm{y}$

$\mathrm{Vx}=$ Variance of the character $\mathrm{x}$ $\mathrm{Vy}=$ Variance of the character $\mathrm{y}$

2. Threshold Value $(\mathrm{T} \mathrm{V})=\mathrm{P}^{(+)}+1.96 \times 6 \mathrm{P}^{(+)}$

Where,

$\mathrm{P}^{(+)}$and $6 \mathrm{P}^{(+)}$are the mean and standard deviation of increasing parent, respectively

The individuals transgressed this threshold limit were considered as the transgressive segregants

\section{Results and Discussion}

The conventional idea of hybridization is to recombine the desirable characteristics in a new hybrid derivative, already observed in two parents involved in hybridization. The occurrence of transgressive segregants in segregating generation suggests that, the concept of transgressive segregation can be used as positive tool in plant breeding. The studies on transgressive segregation in the segregating generation, suggest that parent do not represent the extremes in terms of intensities of desired characters. If some genes for enhanced expression of a character are lacking in the genotype of the increasing parent but are present in donar parent, some individuals among the hybrid derivatives, emanating from the cross of these parents, might receive a fortuitous gene combination showing a larger effect than produced by either of the parents (Gardner, 1968).

It is intresting to note that, in present study, transgressive segregants were recorded in $\mathrm{F}_{2}$ generation for all the six character in this cross (Table 1). In case of grain yield per plant 4.83 percent individuals transgressed beyond the increasing parent. Transgressive 
segregants were 5.16 per cent for plant height, 0.50 per cent for number of primary branches per plant, 2.50 per cent for number of pods per plant, 1.66 per cent for number of seeds per pod and 1.66 per cent for 100-grain weight in this cross.

Mansur et al., (1996) reported transgressive segregants in respect of plant height $(\mathrm{cm})$, number of seeds per pod, pod number and grain yield per plant $(\mathrm{g})$ in $\mathrm{F}_{2}$ generation of soybean. Similar observation also made in mungbean by Karkute et al., (2016) and Sabale and Girase (2018). Ugale and Bahl (1980) reported transgressants for all these characters except pod length and cluster per plant with the highest proportion of individuals for plant spread $(30.77 \%)$. Girase and Deshmukh (2002) and Deokar et al., (2019) reported transgressive segregants in chickpea for all seven characters viz; plant height, plant spread, fruiting branches per plant, pods per plant, seeds per pod, 100-seed weight and yield per plant. They observed the highest transgressive segregation for plant height $(27 \%)$ followed by pods per plant, fruiting branches per plant and yield per plant in both $F_{2}$ and $F_{3}$ generation of all the three crosses.

If we consider transgressive segregants for grain yield per plant in the cross KDS-726 x NRC-102, plant No.379 was found to be most promising as it has given 107.66 per cent more grain yield per plant in addition to higher expression other three traits than the increasing parent (Table 2).

From this investigation, it can be suggested that the most promising transgressive segregant listed in (Table 2) need to be evaluated further. If it confirm their superiority in further generations may be considered for multi-location evaluation for release as a variety or may be used as a parent in future breeding programme.
Apart from the frequency of transgressants, it will be of great interest to examine the intensities of the characters expression achieved in the transgressants in this cross. The character expression achieved by transgressive segregants were 70 to $79 \mathrm{~cm}$ plant height, 89 to 135 pods per plant, 20.24 to $24.80 \mathrm{~g} 100$ grain weight, and 32.46 to $52.85 \mathrm{~g}$ grain yield per plant. This will provide an insight into the extended limits and intensities of desired characters expression achievedby transgressive breeding. In the present investigation, the highest yielding transgressants in present cross produced 52.85 g grain yield per plant, as against $25.45 \mathrm{~g}$ per plant, produced by their respective increasing parents. These intensities for grain yield per plant were 107.66 per cent higher than those of their respective increasing parents. Plant height achieved by transgressive segregants in this cross were suitable for mechanical harvesting.

From this data it is evident that when the desired intensity of a character is not available in the parents, the concept of transgressive segregation can be employed to extend the limit of expression of characters. It is therefore, concluded that transgressive breeding is effective for extending the limit of character expression, if plant breeder is interested in isolating the rare genotypes. In this method we impose more selection pressure which result in the highest recovery of characters than that of other breeding approaches.

Among the phenotypic correlation of grain yield per plant with nine other characters studied in $\mathrm{F}_{2}$ generation of one cross, significant and positive correlation coefficient of grain yield were observed with number of pods per plant $(0.3912)$, number of primary branches (0.2094), and oil content (0.1866) (Table 3). 
Table.1 Threshold value, (T.V.), normal deviation value (N. D.), frequency, percentage and range in the values of transgressive segregants(T.S.) for six characters in $\mathrm{F}_{2}$ generation of cross

KDS-726 x NRC-102

\begin{tabular}{|c|c|c|c|c|c|}
\hline \multirow[t]{2}{*}{ Sr No. } & \multirow[t]{2}{*}{ Characters } & \multicolumn{4}{|c|}{$\begin{array}{c}\text { Transgrassive segregation } \\
\text { F2 generation }\end{array}$} \\
\hline & & $\begin{array}{l}\text { Threshold } \\
\text { Value }\end{array}$ & N.D value & Frequency & Range \\
\hline 1. & Plant height $(\mathrm{cm})$ & 69.28 & 1.45 & $\begin{array}{c}28 \\
(5.16)\end{array}$ & $70.00-79.00$ \\
\hline 2. & Number of primary branches/ plant & 05.75 & 3.36 & $\begin{array}{c}3 \\
(0.50)\end{array}$ & $06.00-07.00$ \\
\hline 3. & Number of pods /plant & 97.67 & 2.19 & $\begin{array}{c}15 \\
(2.05)\end{array}$ & $98.00-135.00$ \\
\hline 4. & Number of seeds/ pod & 2.16 & 2.16 & $\begin{array}{c}10 \\
(1.66)\end{array}$ & $02.70-02.80$ \\
\hline 5. & 100 grain weight $(\mathrm{g})$ & 20.20 & 0.017 & $\begin{array}{c}10 \\
(1.66)\end{array}$ & $20.24-24.80$ \\
\hline 6. & Grain yield per plant (g) & 32.19 & 1.89 & $\begin{array}{c}26 \\
(4.33)\end{array}$ & $32.46-52.85$ \\
\hline
\end{tabular}

*Figures in parenthesis indicates the percentage of transgressive segregants

Table.2 Promising transgressive segreagants having combinations of desirable attributes

\begin{tabular}{|c|c|c|c|c|c|c|c|c|}
\hline Characters & $\begin{array}{l}\text { Plant } \\
\text { No. }\end{array}$ & $\begin{array}{l}\text { PLH } \\
(\mathbf{c m})\end{array}$ & PBP & PPP & SPP & GWT & GRY & $\begin{array}{c}\% \text { yield increased } \\
\text { over increasing Parent }\end{array}$ \\
\hline \multicolumn{9}{|c|}{ Cross: - KDS-726 X NRC-102 } \\
\hline $\mathbf{F}_{2}$ & 379 & $58^{+}$ & 3 & $52^{+}$ & 2.4 & $17.26^{+}$ & $52.85^{+}$ & 107.66 \\
\hline KDS-726 & & 57 & 3 & 51 & 2.4 & 16.28 & 25.45 & \\
\hline NRC-102 & & 51 & 2 & 36 & 2.3 & 17.07 & 14.97 & \\
\hline
\end{tabular}

+: Intensity of expression of character higher than the increasing parent

PLH $(\mathrm{cm})=$ plant height

GWT $=100$-Grain weight $(\mathrm{g})$

$\mathrm{PBP}=$ No.of primary branches/plant6. GRY= Grain yield/plant $(\mathrm{g})$

$\mathrm{PPP}=$ No. of pods/plant

$\mathrm{SPP}=$ No. ofseeds/pod

Table.3 The uppermost limits achieved by transgressives segregants over their increasing parents in respect of various characters in $\mathrm{F}_{2}$ generation

\begin{tabular}{|c|c|c|}
\hline \multirow{2}{*}{$\begin{array}{c}\text { Sr. } \\
\text { No. }\end{array}$} & Character & \multicolumn{2}{|c|}{ Highest intensity of characters expression in cross } \\
\hline $\mathbf{1}$ & KDS-726 X NRC-102 \\
\hline $\mathbf{2}$ & Number of primary branches & $79(58.5)$ \\
\hline $\mathbf{3}$ & Number of pods per plant & $7(3.3)$ \\
\hline $\mathbf{4}$ & Number of seeds per pod & $135(72.8)$ \\
\hline $\mathbf{5}$ & 100-grain weight $(\mathrm{g})$ & $2.8(2.45)$ \\
\hline $\mathbf{6}$ & Grain yield per plant $(\mathrm{g})$ & $24.8(17.07)$ \\
\hline
\end{tabular}

* Figures in bracket are the mean values of respective increasing parent 

Table.4 Phenotypic correlation coefficients between different pairs of characters in $\mathrm{F}_{2}$ generation of cross KDS-726 X NRC-102

\begin{tabular}{|c|c|c|c|c|c|c|c|c|c|c|}
\hline Characters & $\begin{array}{c}\text { Days to } \\
50 \% \\
\text { Flowering }\end{array}$ & $\begin{array}{l}\text { Days to } \\
\text { Maturity }\end{array}$ & $\begin{array}{l}\text { Plant } \\
\text { height }\end{array}$ & $\begin{array}{c}\text { No. of } \\
\text { primary } \\
\text { branches/ } \\
\text { plant }\end{array}$ & $\begin{array}{c}\text { No. of } \\
\text { pods/plant }\end{array}$ & $\begin{array}{c}\text { No. of } \\
\text { seeds/pod }\end{array}$ & $\begin{array}{l}\text { 100-grain } \\
\text { weight }\end{array}$ & $\begin{array}{c}\text { Oil } \\
\text { content } \\
(\%)\end{array}$ & $\begin{array}{c}\text { Ptoten } \\
\text { content } \\
(\%)\end{array}$ & $\begin{array}{c}\text { Grain } \\
\text { yield/plant }\end{array}$ \\
\hline $\begin{array}{c}\text { Days to } 50 \% \\
\text { flowering }\end{array}$ & - & 0.0254 & 0.0336 & -0.0030 & 0.0030 & 0.0341 & 0.0173 & $0.2207 * *$ & $-0.1715 * *$ & -0.0006 \\
\hline Days to maturity & & - & 0.0719 & $-0.0832 *$ & -0.0412 & 0.0288 & 0.0506 & -0.0496 & $0.2151 * *$ & -0.0766 \\
\hline Plant height (cm) & & & - & -0.0407 & -0.0312 & 0.0653 & -0.0044 & $-0.3687 * *$ & 0.0351 & -0.0367 \\
\hline $\begin{array}{l}\text { Number of primary } \\
\text { branches per plant }\end{array}$ & & & & - & $0.5317 * *$ & 0.0485 & -0.0534 & $-0.1056^{*}$ & $0.2783^{* *}$ & $0.2094 * *$ \\
\hline $\begin{array}{c}\text { Number of pods per } \\
\text { plant }\end{array}$ & & & & & - & 0.0653 & -0.0358 & -0.0495 & 0.0767 & $0.3912 * *$ \\
\hline $\begin{array}{c}\text { Number of seeds per } \\
\text { pod }\end{array}$ & & & & & & - & -0.0409 & $0.3491 * *$ & $-0.3339 * *$ & 0.0468 \\
\hline 100-grain weight $(\mathrm{g})$ & & & & & & & - & $-0.3159 * *$ & $-0.2801 * *$ & -0.0159 \\
\hline Oil content (\%) & & & & & & & & - & $-0.2138 * *$ & $0.1866 *$ \\
\hline Protein content (\%) & & & & & & & & & - & $-0.2242 * *$ \\
\hline \multicolumn{2}{|c|}{ *,** Significant @ 5\%, } & \multicolumn{3}{|c|}{ and $1 \%$, level, respectively. } & & & & & & \\
\hline
\end{tabular}


The seeds per pod showed positive correlation with grain yield. These characters also showed positive and significant correlation among themselves uniformly in $\mathrm{F}_{2}$ generation. The days to flowering, days to maturity, plant height, 100-grain weight, and protein content had negative correlation with grain yield per plant.

The days to maturity and primary branches per plant exhibited positive significant correlation with protein content. Significant positive and highest correlation was observed between number of primary branches per plant and number of pods per plant (0.5313), both are important traits for grain yield. Significant association of these traits with grain yield have been previously reported by Preetipainkara et al., (2018). She reported significant positive correlation among yield contributing characters like number of primary branches, number of pods per plant and number of seeds per pod as observed in present study.

The positive and significant correlation of grain yield per plant with number of primary branches per plant, number of pods plant, and number of seeds per pod, are in accordance with those obtained by Girase and Deshmukh (2002); Saharan et al.,(2006) and Dubey et al., (2015). Haghi et al., (2012) reported negative correlation between oil content and protein content with grain yield per plant. Chavan et al., (2016) reported highly significant and positive correlation of grain yield per plant with number of pods per plant, and 100-seed weight. The correlation coefficient was positive between days to $50 \%$ flowering, plant height $(\mathrm{cm})$ and 100 grain weight. The Balla and Ibrahim (2017), and Preetipainkara et al., (2018) observed significant positive correlation of grain yield with number of primary branches per plant, number of pods per plant and number of seeds per pod (Table 4).

\section{References}

Anonymous (2019-20). Area \& Production Estimates of Soybean [Glycine max (L.) Merrill], Crop survey conducted by SOPA. in India in Kharif 2019 -20.

Ball M. Y., Ibrahim S. E. (2017). Genotypic correlation and path coefficient Analysis of Soybean [ Glycine max (L.) Merr.] For yield and its components. Agri Res \&Tech: Open Access J.; 7 (3); 555715. DOI: DOI: 10.19080 / ARTOAJ. 2017. 07. 555715

Chavan B. H., D.V. Dahat, H.J. Rajaput., M. P. Deshmukh and S.L. Diwane (2016). Correlation and Path Analysis in Soybean. International Research Journal of Multidiciplinary Studies. Vol 2 ISSN (online) : 2454 - 8499

Dewey, D. R. and K. H. Lu. (1959). Correlation and path analysis of crested wheat grass seed production. Journal of Agronomy, 51: 515-518.

Deokar S.D., V. S. Girase, S. G. Patil and V. V. Bhavsar. (2019). Assessment and implication of selection indices in $\mathrm{F}_{2}$ Generation of chickpea (cice rarientinum L.), International Journal of Current Microbiology and Applied science. 8(10). 934-939.

Dubey N., Shrivasthava A. N., Avinashe H. A. and Samidha J. 2015. Genetic diversity, correlation and path analysis for yield and yield contributing characters in soybean (Glycine max L.). Electronic Journal Plant Breeding 6(1): 318-325.

Gardner, E. J. 1968. Principle of Genetics. John Wiley and sons, New York, pp. 405.

Girase, V. S. and R. B. Deshmukh (2002) Transgressive segregation of grain yield and its components in Chickpea. J. Maharashtra agric. Univ., 27(1):015-018. 
Haghi Y., Boroomandan P., Mordin M., Hassankhali M., Farhadi P., Farsaei F. and Dabiri S. 2012. Correlation and path analysis for yield, oil and protein content of soybean genotypes under diffrent levels of nitrogen starter and plant density. Biharian Bio., 6 (1): pp. 32-37.

Karkute, S. M., V. S. Girase and A. J. Patil. 2016. Transsgressive segregation and in mungbean [Vigna radiate L.) Wilczek]. Journal of Agriculture Research and Technology, 41(1):4851.

Painkara P., R. Shrivastava., S.K. Nag and I. Kute (2018) Correlation analysis for seed yield and Its Attributing Traits in soybean (glycine maxL.Merill) . International journal of current Microbiology and applied sciences. 7(4): 2034-2040
Panse, V. G. and P. V. Sukhatme. 1967. Statistical methods for Agricultural Workers. ICAR, New Delhi, pp. 359.

Sabale V. B. and V. S. Girase. 2018. Transgressivesegregation analysis in mungbean (Vigna radiatan (L) wilczek.). Contemporary Research in India, 5: 310-313.

Saharan R. K., Sharma S. P., Ranwah B. R. and Sharma V. 2006.Path analysis for yield and quality traits in soybean.National J. Plant Improve., 8 (1): 44-46.

Ugale, S. D. and P. N. Bhal.(1980) Incorporation of germplasm from Kabuli to Deshi and vice versa in Chickpea (Cicer arientinum L.)IndiaOxford and IBH. Publishing co-, New Delhi, pp 646.

\section{How to cite this article:}

Tagad, B. A., V. S. Girase, Rohini Y. Patil and Bhavsar, V. V. 2020. Transgressive Segregation and Interrelationship Analysis in Soybean. Int.J.Curr.Microbiol.App.Sci. 9(12): 379-386. doi: https://doi.org/10.20546/ijcmas.2020.912.048 